\title{
Metode Hermeneutik dalam Pendidikan
}

\author{
Sembodo Ardi Widodo \\ Universitas Islam Negeri Sunan Kalijaga \\ sembodo_aw@yahoo.com
}

\begin{abstract}
Hermeneutics is an art of interpretation or a philosophical study of understanding. It has wider range of understanding; not only canonical texts, but also all texts, from teaching manuals to literary classics. Human acts and products, such as the act of teaching and the institution of school or university are interpreted. Here, we can see that the formulation of vision, mission, and the goal of any school and university is a result of interpretation or dialogue. Not only in this educational aspect hermeneutics plays its role, but also in teaching-learning aspect. According to hermeneutics, teaching is an art, not a science or technology. Teaching-learning process is like a dialogue or game in which participants are carried by something larger than themselves toward an insight they have not anticipated. Dialogue presupposes a subject and a desire to understand it. Openness on both sides is essential. No one must come with his mind made up. In a give and take, each participant arrives at a new understanding. Finally, genuine dialogue makes fusion of each participant's mental horizon.
\end{abstract}

Keywords: hermeneutics, interpretation, philosophy, understanding, education.

\section{Pendahuluan}

Lermeneutika sebagai bagian dari filsafat Idan metode berpikir sering digunakan dalam kajian human sciences. Dalam empat dasawarsa belakangan ini, hermenetika muncul kepermukaan sebagai salah satu alternatif pendekatan keilmuan yang bisa dikatakan sebagai respon terhadap filsafat positivisme yang "menyangga" peradaban modern akan tetapi tidak memberikan solusi bagi problem-problem kemanusiaan yang muncul akibat berbagai kemajuan di bidang teknologi, industri, dan informasi.

Secara historis, pada masa Yunani Kuno, hermeneutika sudah menjadi wacana dan kajian filsafat. Kemudian pada masa scholastik, para teolog Kristen menggunakan metode hermeneutik untuk menginterpretasikan Kitab Suci, dan para hakim menggunakannya ketika menerapkan hukum lama untuk kasus-kasus baru yang sebelumnya belum pernah muncul.
Pada abad ke-19, beberapa filosof Jerman, terutama sekali Wilhelm Dilthey menganggap bahwa interpretasi sesungguhnya adalah pusat bagi pemahaman dalam skala luas, tidak hanya interpretasi atas teks-teks hukum, tetapi meliputi semua teks, dari literatur-literatur kuno sampai pada teks atau materi pembelajaran. Selain itu, perbuatan dan hasil karya manusia seperti tindakan-tindakan dalam pembelajaran dan institusi sekolah juga dapat diinterpretasikan (Kneller,1984).

Ada keterkaitan antara teks dan tindakan. Suatu tindakan, seperti tindakan dalam pembelajaran adalah penuh makna. Memahaminya serupa dengan memahami sebuah teks. Dalam setiap kasus kita bermaksud mendapatkan apa yang dicari oleh pengarang untuk diselesaikan. Untuk melakukan hal itu, kita mengambil alih tempatnya, mengasumsikan anggapananggapan dan menyelami pemikirannya. 
Metode Hermeneutik dalam Pendidikan; Sembodo Ardi Widodo

Dilthey menyebut proses ini dengan "pemahaman empatik" atau Verstehen.

Pemahaman empatik, bagi Dilthey merupakan metode yang benar bagi studistudi kemanusiaan (human studies). Human Studies, termasuk di dalamnya studi kependidikan mengkaji tindakan dan hasil karya manusia sebagai "ekspresi" kehidupan bagian dalam pengarang atau penciptanya. Untuk memahami ekspresi seperti itu, kita harus merekonstruksi apa yang dimaksud oleh pengarang. Untuk memahami sekolah misalnya, kita harus bertanya tentang apa yang dicita-citakan oleh mereka yang terlibat dalam pengembangan sekolah tersebut (Ibid., p. 66-67)

Tulisan ini dimaksudkan untuk mengkaji lebih mendalam bagaimana hermeneutika itu menjadi wacana dalam dunia pendidikan dan sekaligus sebagai salah satu alternatif metode pembelajaran.

\section{Kajian Pustaka}

\section{Makna Hermeneutika}

Akar kata hermeneutika berasal dari kata kerja bahasa Yunani hermeneuein, yang secara umum diterjemahkan "to interpret", dan kata bendanya hermeneia yang berarti "interpretation". Eksplorasi atas asal usul dua kata ini membawa kita kepada penggunaannya pada masa lampau dalam wilayah teologi dan literatur. Hermeneuein dan hermeneia dalam berbagai bentuknya telah dipakai dalam teks-teks klasik seperti yang ditulis oleh Aristoteles dalam Peri Hermeneias atau On Interpretation, yaitu bahwa kata-kata yang kita ucapkan adalah simbol dari pengalaman mental kita, dan kata-kata yang kita tulis adalah simbol dari kata-kata yang kita ucapkan. Selain Aristoteles, dua kata tersebut digunakan oleh para penulis atau filosof klasik seperti Plato, Xenophon, Plutarch, Euripides, Epicurus, Lucretius, dan Longinus (Palmer,1969).

Munculnya istilah hermeneuein atau hermeneia terkait dengan tokoh mitologis, Hermes, yaitu seorang utusan yang mempunyai tugas menyampaikan pesan Jupiter kepada manusia. Hermes digambarkan sebagai seseorang yang mempunyai kaki bersayap. Tugas Hermes adalah menerjemahkan pesan-pesan dari dewa di Gunung Olympus ke dalam bahasa yang dapat dimengerti oleh umat manusia. Tugas Hermes ini sangat penting bagi kehidupan manusia, karena jika terjadi kesalahpahaman manusia dalam memahami pesan-pesan dewa maka akibatnya akan fatal bagi seluruh umat manusia. Hermes harus mampu menginterpretasikan pesan ke dalam bahasa yang dipergunakan oleh pendengarnya. Sejak saat itu Hermes menjadi simbol seorang duta yang mengemban misi tertentu. Keberhasilan misi ini tergantung sepenuhnya pada metode bagaimana misi itu disampaikan. Oleh karena itu, hermeneutika pada akhirnya diartikan sebagai proses mengubah sesuatu atau situasi ketidaktahuan menjadi mengerti (Sumaryono,1999).

Misi "memahamkan pesan kepada umat manusia" yang diemban oleh Hermes ini secara implisit berhubungan dengan tiga dasar makna direktif hermeneuein dan hermeneia. Tiga makna direktif ini digunakan untuk tujuan seperti: 1) Mengekspresikan suara dalam kata-kata, atau "mengatakan". 2) Menjelaskan, seperti menjelaskan situasi, dan 3) menerjemahkan, seperti menerjemahkan bahasa asing ke dalam bahasanya sendiri. Ketiga arti ini dapat diekspresikan dengan kata "to interpref" atau "menafsirkan". Masing-masing tujuan 
menentukan independensi dan signifikansi makna interpretasi. Suatu interpretasi, oleh karenanya, dapat merujuk kepada ketiga tujuan tersebut. Seseorang dapat mencatat bahwa fondasi "proses Hermes" adalah kerja; dan kerja dalam ketiga kasus tersebut kadang-kadang berbentuk asing, keterpisahan dalam waktu, ruang, atau pengalaman, dan kadang-kadang membutuhkan representasi, eksplanasi, atau terjemahan yang membawa konsekuensi pemahaman. Semua hal tersebut perlu diinterpretasikan (Palmer,1969).

Interpretasi literal dapat dimasukkan dalam kerangka interpretasi ini. Wilayahnya bisa mencakup proses pertama dan kedua (mengatakan dan menjelaskan), atau bahkan mencakup proses yang ketiga (menerjemahkan). Literatur membuat representasi dari sesuatu yang harus dipahami. Suatu teks bisa jadi terpisah di dalam subyeknya dari kita yang disebabkan oleh waktu, tempat, bahasa, dan rintanganrintangan lain dalam memahami. Hal ini dapat juga terjadi dalam memahami teks skriptural atau kitab suci. Tugas interpretator harus menjadikan sesuatu yang tidak familier, jauh, dan kabur maknanya menjadi sesuatu yang riil, dekat, dan dapat dinalar. Aspek yang beragam dari proses interpretasi ini sangatlah vital dan integral dalam kajian literatur dan demikian juga dalam kajian teologi.

Dalam kajian filsafat sejarah dan ilmuilmu sosial (social sciences) dibedakan antara penjelasan (eksplanasi) tindakan dan keyakinan-keyakinan manusia dan pemahaman maknanya, yakni antara penjelasan mengapa ada tindakan atau keyakinan tertentu dalam kehidupan dan pemahaman agen apa yang terlibat dalam gerakan-gerakan atau keyakinan-keyakinan apa yang merepresentasikan hal itu.
Kalangan "positivis" menegaskan bahwa pemahaman makna mencakup rekonstruksi imajinatif intensi dan tujuan aktornya. Rekonstruksi semacam itu bermanfaat untuk memformulasikan sebuah hipotesis dengan mencoba menjelaskan sebab-sebab munculnya tindakan. Namun demikian, pemahaman tidak bisa dimasukkan sebagai bagian dari logika keilmuan itu sendiri. Aspek ilmiah dari studi tindakan (tingkah laku) cenderung mengkonstruksi penjelasan hipotesis yang dapat dimasukkan dalam teori-teori umum tingkah laku manusia, dan mengujinya melalui metode-metode observasi empirik yang reliable. Dari sini, kemudian dapat dirumuskan hukum-hukum atau teori-teori universal yang dengannya dapat meramalkan atau menjelaskan peristiwa atau tindakan-tindakan yang akan terjadi (Gadamer,1987).

Berbeda dengan model penjelasan ini, teori hermeneutika menegaskan bahwa logika sejarah dan ilmu sosial tidak sama dengan logika ilmu kealaman (natural sciences), karena pemahaman interpretatif bermain di dalamnya. Dalam pandangan ini, memahami tindakan atau keyakinan tertentu termasuk bagian dari tugas ilmiah itu sendiri yang mencoba menjelaskan mengapa hal itu terjadi. Tugas ini mencakup "membaca" situasi, menempatkan gerakangerakan dan kata-kata dalam konteks pemahaman dengan warna tindakan atau keyakinan yang lain. Dalam kerangka pemahaman model inilah Gadamer membangun pemikiran hermeneutiknya. Gadamer membedakan antara dua bentuk pemahaman, yakni pemahaman kebenaran isi dan pemahaman intensi. Yang pertama merujuk kepada bentuk pengetahuan substanstif. Di sini, pemahaman berarti melihat "kebenaran" sesuatu. Bentuk pemahaman kedua, berlawanan dengan yang pertama, mencakup pengetahuan 
Metode Hermeneutik dalam Pendidikan; Sembodo Ardi Widodo

kondisi, yakni alasan di balik klaim seseorang. Pemahaman seperti ini mencakup juga pemahaman psikologis, biografis, atau kondisi historis di belakang suatu klaim atau tindakan sebagai oposisi terhadap pemahaman substantif suatu klaim atau tindakan itu sendiri. Apa yang dipahami bukan isi kebenaran suatu klaim atau poin tindakan tertentu, tetapi dorongan-dorongan di belakang rekayasa seseorang atas klaim atau tindakan (Ibid;Gadamer, 1987).

\section{Bidang-bidang Hermeneutika}

Dalam sepanjang sejarahnya, hermeneutika secara sporadis tumbuh dan berkembang sebagai teori interpretasi saat ia diperlukan untuk menerjemahkan literatur otoritatif di bawah kondisi-kondisi yang tidak mengijinkan akses kepadanya karena alasan jarak ruang dan waktu atau pada perbedaan bahasa. Sebagai cara untuk memperoleh pemahaman yang benar, hermeneutika pada awalnya dipergunakan dalam tiga jenis kapasitas: pertama, membantu diskusi mengenai bahasa teks, yaitu kosa kata dan tata bahasa, yang pada gilirannya memunculkan filologi; kedua, memfasilitasi eksegesis literatur suci; dan ketiga, menuntun yurisdiksi (Gadamer, 1987).

Hermeneutika belakangan ini muncul dalam diskursus filsafat ilmu-ilmu sosial, filsafat seni dan bahasa, dan dalam kritik sastra. Persoalan-persoalan hermeneutika yang berpusar pada subyektivitas dan obyektivitas makna segera memunculkan bidang-bidang hermeneutika yang jelas-jelas terpisah, yaitu teori hermeneutika, filsafat hermeneutika, dan hermeneutika kritis.

Teori hermeneutika memusatkan diri pada persoalan teori umum interpretasi sebagai metodologi bagi ilmu-ilmu humaniora. Sasaran yang ingin dicapai oleh teori hermeneutika adalah sebuah pemahaman makna "yang relatif objektif" dengan menggunakan serangkaian aturan yang telah dirumuskan dalam rangka memfasilitasi interpretasi yang benar. Teori hermeneutika sebagai epistemologi dan metodologi pemahaman selanjutnya dikembangkan oleh Dilthey. la berurusan dengan epistemologi dalam konteks "Critique of Historical Reason" yang mengusahakan sebuah penelitian transendental atas kondisi-kondisi mengenai kemungkinan pengetahuan historis dengan mengikuti contoh yang telah disediakan oleh Kant dalam "Critique of Pure Reason". Dilthey mempertajam aspek metodologisnya menjadi interpretasi atas dokumendokumen yang secara linguistik sempurna (Bleicher, 2007).

Filsafat hermeneutika memperingatkan kita akan bahaya obyektivisme di balik pendekatan metodis dan obyektivikasi atas interpretasi ekspresi-ekspresi manusia. Dengan mengembangkan kesadaran mengenai "pra struktur" pemahaman filsafat hermeneutik menghindarkan lebih jauh asumsi naif mengenai adanya pengetahuan yang obyektif atau netral sepenuhnya, berdasarkan kenyataan bahwa kita sesungguhnya menginterpretasikan obyek sebagai sesuatu sebelum kita menginvestigasinya (Bleicher:395-396,2007). Salah satu pandangan utama filsafat hermeneutik menegaskan bahwa ilmuwan sosial atau interpretator dan obyek yang diinterpretasikan pada prinsipnya telah dihubungkan oleh sebuah konteks tradisi. Hal ini mengindikasikan, bahwa ia telah memiliki sebuah pra-pemahaman atas objek tersebut, sehingga tidak mungkin untuk memulai dengan sebuah pemikiran yang netral. Filsafat hermeneutik tidak bertujuan mencapai sebuah pengetahuan objektif dengan menggunakan prosedur-prosedur metodis, melainkan pada pengungkapan dan deskripsi fenomenologis mengenai Dasein 
UNISIA, Vol. XXXI No. 70 Desember 2008

manusia dalam temporalitas dan historisitasnya (Bleicher:ix-x,2007).

Dalam perkembangan selanjutnya, hermeneutik meluas menjadi sebuah metode kritik yang secara sistematis mengubah bentuk komunikasi. Apel dan Habermas melangkah pada bidang hermeneutika kritis ini. Mereka mengkombinasikan pendekatan metodik dan objektif dengan mengusahakan pengetahuan yang secara praktis relevan. Yang dimaksud "Kritis" di sini secara umum adalah penaksiran atas hubungan-hubungan yang telah ada dalam pandangan standar yang berasal dari pengetahuan mengenai sesuatu yang lebih baik yang telah ada sebagai sebuah potensi atau tendensi di masa kini; ia dituntun oleh prinsip rasio sebagai tuntutan komunikasi tanpa tekanan dan pembatasan diri (Bleicher:xii,2007).

\section{Pendidikan Sebagai Kajian Hermeneutik}

Untuk pembahasan tentang "peleburan" pendidikan dalam pembahasan hermeneutika, saya harus kembali kepada pengertian hermeneutika sebagaimana yang dipahami oleh Richard Palmer. Menurut Palmer, hermeneutika adalah sebuah teori yang mengatur tentang metode penafsiran, yaitu interpretasi terhadap teks dan tandatanda lain yang dapat dianggap sebagai teks (Palmer,1969). Perluasan makna teks ini berimbas kepada interpretasi wacana-wacana lain selain teks yang tertulis itu sendiri. Paul Recoeur, misalnya memperluas konsep teks kepada setiap tindakan yang disengaja untuk mencapai tujuan tertentu. Pengertian ini dikembangkan oleh Recoeur untuk membangun sebuah epistemologi baru bagi ilmu-ilmu sosial maupun humaniora. la menganggap bahwa objek kajian dari ilmuilmu sosial dan humaniora memiliki karakter sebagai teks; oleh karena itu, metodologi yang digunakannya harus berupa metodologi yang menyerupai kajian interpretatif yang ada dalam hermeneutika (Recoueur, 2005).

Selain Recoeur, sebelumnya Gadamer juga telah memperluas kajian hermenetika dalam berbagai bidang. Dalam karyanya "Hermeneutics, Religion, and Ethics", Gadamer secara nyata menerapkan hermeneutika dalam kajian keagamaan dan etika. Bahkan dalam salah satu pembahasannya, la mendialogkan antara agama dan sains. Bagaimana kita memahami kembali agama (Kristen) yang dulu berada di bawah otoritas gereja dan makna agama yang sekarang dikelilingi oleh kemajuan sains. Di sinilah Gadamer telah menerapkan analisis hermeunetiknya secara menarik (Gadamer, 1999).

Pendidikan sebagai eksistensi yang ada di dunia ini adalah suatu realitas sosial, realitas yang memuat aktivitas atau tindakan-tindakan tertentu yang oleh aktoraktornya dikembangkan untuk tujuan tertentu. Pendidikan dengan segala aspek yang terkandung di dalamnya seperti visi, misi, dan tujuan lembaga, kurikulum, dan strategi pembelajarannya adalah sekumpulan teks atau wacana yang bisa dimasuki berbagai interpretasi. Sebagai sebuah teks atau wacana, pendidikan oleh karenanya menjadi lahan subur penerapan hermeneutika, baik sebagai metode, filsafat, maupun kritik.

Perubahan paradigma pendidikan yang ada di Indonesia pada dasarnya adalah hasil dari sebuah interpretasi aktor-aktornya melalui proses dialogis dengan realitas empirik, dengan dinamika perkembangan iptek, globalisasi, tuntutan dunia kerja, demokrasi, pluralisme, dan ideologi-ideologi lainnya yang sekarang ini terus menjadi wacana eksistensial.

Lembaga pendidikan dengan segala kandungannya adalah sebuah mekanisme, 
Metode Hermeneutik dalam Pendidikan; Sembodo Ardi Widodo

struktur, dan sekaligus menjadi wadah bagi lahirnya interpretasi sebagaimana dibakukannya wacana dalam teks. Jika teks tidak bisa lepas dari interpretasi, maka lembaga pendidikan pun tidak bisa dilepaskan dari interpretasi, yang kemudian terwujud dalam visi, misi, dan tujuan, serta diimplementasikan dalam kurikulum dan proses pembelajaran.

Tidak hanya itu saja, kompetensi yang sekarang ini menjadi acuan dalam pengembangan kurikulum juga merupakan proses interpretasi. Merumuskan sebuah kompetensi pada hakikatnya adalah sebuah interpretasi, yaitu menginterpretasikan kemampuan atau kecakapan dengan tuntutan dunia luar dalam berbagai aspek. Guru dalam merumuskan kompetensi tidak ubahnya sebagai seorang hermenet yang berusaha menerjemahkan atau menginterpretasikan bagaimana sebuah kompetensi itu sesuai dengan kebutuhan dan tuntutan riil di lapangan.

Dalam skala yang lebih luas, untuk menegaskan bahwa pendidikan itu tidak bisa dilepaskan dari hermeneutika, kita bisa menanyakan mengapa dalam sejarah perkembangan pendidikan Islam di Indonesia terjadi heterogenitas lembaga pendidikan; ada pesantren, sekolah, madrasah, dan lembaga-lembaga non formal lainnya. Ini tidak lain adalah hasil interpretasi. Interpretasi ini terus berkembang sampai pada hal-hal yang fundamental yang dipengaruhi oleh faktor-faktor ideologis, ekonomis, maupun politis, sehingga melahirkan visi, misi, tujuan, dan kurikulum yang relatif berbeda walau pun lembaganya sama. Sekarang ini banyak kita jumpai sekolah-sekolah yang berbeda visi, misi, dan tujuannya antara sekolah yang satu dengan yang lainnya. Demikian juga dengan pesantren, madrasah, dan perguruan tinggi.
Dalam perjalanan pendidikan Islam di Indoensia, kita melihat adanya interpretasiinterpretasi yang dilakukan oleh organisasiorganisasi keislaman seperti Muhammadiyah, al-Irsyad, Mathla'ul Anwar, dan NU dalam masalah pendidikan. Masingmasing mendirikan lembaga-lembaga pendidikan. Muhammadiyah dan al-Irsyad lebih cenderung mengembangkan sekolah(Nata,1997), Mathla'ul Anwar mengaktualisasikan pendidikan Islam dengan sistem madrasah (Djuwaeli,1997) dan NU lebih mengutamakan pendidikan Islam ala pesantren. Masing-masing organisasi mempunyai ideologi sendirisendiri. Dalam peta pembaharuan Islam di Indonesia, secara kasar barangkali bisa dipetakan sebagai berikut; Muhammadiyah (juga al-Irsyad): modernis-puritan, Mathla'ul Anwar: modernis-moderat, dan NU: modernis-kultural. Dengan meminjam kacamata Gadamer, kita bisa melihat di sini bahwa tradisi, dalam hal ini adalah ideologiideologi keagamaan Islam, turut mempengaruhi interpretasi atas eksistensi pendidikan.

Dalam wilayah keagamaan dan pendidikan, kita bisa mengambil contoh analisis hermeneutik yang dipraktekkan oleh K.H. Ahmad Dahlan dalam menentukan tindakan dan tujuan. Dalam menafsirkan alQur'an, K.H. Ahmad Dahlan berusaha mendialogkannya secara intens, kritis, dan serius dengan realitas historis kekhalifahan dan keumatan yang selalu berubah-ubah (Suara Muhammadiyah,2000).Ketika menafsirkan surah al-Mâ'ûn, beliau tidak memahaminya secara tekstual, tetapi mendialogkannya secara hermeneutis dengan realitas historis yang konkret dalam kehidupan sehari-hari, lalu diwujudkan dalam bentuk amal nyata. Sebagai buahnya adalah didirikannya rumah miskin, yayasan yatim piatu, dan rumah sakit. Begitu juga 
UNISIA, Vol. XXXI No. 70 Desember 2008

halnya dalam memahami normativitas wahyu yang berkenaan dengan perintah "membaca" dan menuntut ilmu, beliau juga mendialogkannya dengan realitas historis pada saat itu, yaitu arus modernisasi yang dibawa oleh Belanda dengan model pendidikan ala sekolah yang mengajarkan ilmu-ilmu umum modern dan realitas umat Islam yang masih memahami ilmu agama itu terbatas pada ilmu-ilmu Islam klasik seperti figh, tauhid, hadis, al-Qur'an, kalam, dan lainnya dalam lembaga pendidikan model pesantren. Dan sebagai hasil penafsirannya adalah didirikannya sekolahsekolah umum dan perguruan tinggi Muhammadiyah ((Suara Muhammadiyah, 1996).

Demikian juga dalam hal pemurnian agama, beliau juga mempertanyakan dan mendialogkan antara pesan doktrin dan realitas yang ada di masyarakat; apakah adat kebiasaan dan kepercayaan yang berkembang di masyarakat sesuai dengan al-Qur'an dan hadis. Ternyata beliau melihat ada yang tidak sesuai antara doktrin dan kenyataan. Kemudian beliau bergerak meluruskan ajaran Islam dengan salah satu caranya yakni memberantas bid'ah dan khurafat (Asrofie,1983).

Apa pun yang terjadi dan berlangsung dengan kerja-kerja sosial Muhammadiyah dengan berbagai kekurangan dan kelebihannya, itu semua adalah hasil interpretasi atas teks keagamaan yang berimplikasi dalam dimensi ideologi, sosial, dan pendidikan.

\section{Pembahasan}

Pembelajaran, menurut Gadamer, adalah dialog dalam kerangka tradisi. Guru menginterpretasikan karya-karya, peristiwa, atau teks-teks budaya dan peradaban. Guru menjadi penafsir (interpreter) dari sebuah tradisi. Tugas guru tidak hanya sekedar mentransmisikan tradisi agar siswa dapat menafsirkannya, tetapi lebih dari itu, guru memberi jalan bagi tradisi itu sendiri untuk berjalan terus secara kontinyu. Walaupun guru memegang otoritas, namun pengetahuan dan skillnya digunakan untuk memberikan semangat kepada siswa-siswa agar mau berpikir melalui apa yang mereka interpretasikan daripada sekedar menelan informasi secara mentah-mentah (Kneller,1984).

Model yang digunakan dalam metode pembelajaran seperti itu adalah dialog, di mana dua atau lebih dari siswa-siswa yang ada yang semuanya membawa pengetahuan dan pandangan yang terbatas, secara bersama-sama mencapai pemahaman yang tidak diantisipasi sebelumnya. Dialog memberikan ruang bagi kebenaran untuk memunculkan diri dan dapat dimengerti oleh setiap siswa. Sebagai guru, secara jelas dia adalah pemimpin dari siswa; tetapi dalam sebuah dialog dia tidak boleh memberikan ramalan atau penafsiranpenafsiran yang mungkin muncul, kapan dan bagaimana modelnya. Dialog mempunyai momentum untuk melahirkan interpretasinya sendiri. Setiap siswa mempertanggungjawabkan dirinya, mengambil posisi yang belum pernah ia pertaruhkan sebelumnya. Gadamer mengkontraskan proses ini dengan resitasi, di mana ia mengatakan, bahwa siswa memberikan kepada guru sebuah jawaban yang diharapkan. Resitasi ini akan mengetahui apa yang akan muncul dari ide-ide yang keluar secara spontan. Akhir dari dialog adalah pandangan (insight) dan penemuan (discovery). Yang dimaksud penemuan (discovery) di sini adalah membuka arti dan makna yang terkandung dalam materi pembelajaran ketika terjadi diskusi. Dengan kata lain, materi memberikan ruang wacana untuk 
Metode Hermeneutik dalam Pendidikan; Sembodo Ardi Widodo

diinterpretasikan secara dinamis dan menyeluruh. Apa yang ditemukan dalam dialog tidak harus berupa proposisi praeksistensi, tetapi satu dari kemungkinankemungkinan interpretasi dari teks, tradisi, atau materi yang tidak terhingga jumlahnya (Kneller, 1984).

Dialog diproses melalui tanya-jawab. Ada beberapa alasan untuk hal itu. Pertama, menurut Gadamer, materi atau teks itu sendiri adalah sebuah jawaban atas sebuah pertanyaan atau banyak pertanyaan. Misalnya, sejarah Perang Kemerdekaan Amerika yang komprehensif menceritakan mengapa perang meletus, bagaimana peristiwanya, bagaimana akhir dan hasilnya. Kedua, bahwa siswa-siswa, terlepas dari interesnya terhadap materi, menanyakan persoalan-persoalan di atas. Sementara guru akan memberi stimulus kepada mereka untuk memecahkan persoalan-persoalan tersebut. Oleh karena itu, guru akan menanyakan kepada mereka untuk mengelisitasi pra-konsepsi-nya, yaitu ideidenya yang terkait dengan materi (Ibid).

Dialog yang sejati mensyaratkan adanya subjek dan keinginan yang kuat untuk memahaminya. Keterbukaan atas kedua aspek ini merupakan masalah yang esensial. Seseorang tidak harus memaksakan pandangannya untuk diterima. Dialog berada dalam format memberi dan menerima (in the give and take), yang diharapkan adalah sebuah pemahaman yang baru. Setiap siswa bisa menumpahkan pandangannya atau merubahnya jika hal itu dirasakan kurang kuat argumentasinya. Jika diskusi berjalan sukses, horizon mental kita akan bertemu, selanjutnya siswa dan guru akan melihat kesamaan elemen atau struktur yang terkandung dalam subjek atau materi walaupun masing-masing dari kita menginterpretasikannya secara berbeda. Misalnya, kita menyetujui bahwa Perang
Kemerdekaan US mengandung sekian banyak kejadian dan sebab-sebabnya, namun kita juga dapat membedakannya dan membubuhkan hal-hal (peristiwa dan sebabsebab) yang penting terhadapnya. Akhirnya, pandangan baru muncul, yaitu sebuah pencarian pemahaman yang belum pernah ditentukan sebelumnya. Sekarang terjadilah apa yang dikatakan oleh Gadamer "the fusion of horizons". Sebagai hasil dari diskusi, masing-masing dari kita sekarang membawa mind-set yang sama terhadap subjek (materi). Kita semua melihat, misalnya, bahwa Perang Kemerdekaan adalah sebuah bentuk perang tertentu atau yang secara luas merupakan hasil dari bentuk sebabsebab tertentu. Walapun demikian, kita boleh saja tidak setuju terhadap hal-hal yang spesifik dalam kerangka kerja atau hasil diskusi tersebut (lbid).

Dialog yang sukses akan merubah guru dan siswa. Dalam pandangan Gadamer disebutkan "The participants part from one another as changed beings. The individual perspectives with which they entered upon the discussion have been transformed, and so they are transformed themselves" (Gadamer, 1981). Guru harus familier dengan materi dalam wacana yang baru. Dia bisa merasakan sesuatu yang baru dari pandangan siswa-siswanya. Dia bisa berubah melalui beberapa cara, dan harus lebih apresiatif terhadap sejarah dan urusanurusan publik. Oleh karena itu, guru harus banyak membaca dan mengamati perubahan sosial dan wacana yang berkembang. Pengetahuan dan pandangan kita bersifat tentatif, karena materi selalu terbuka bagi banyak interpretasi, dan interpretasi kita merefleksikan horizon kita yang sekarang.

Siswa-siswa mengikuti proses interpretasi yang serupa ketika mereka membaca teks atau mengkaji materi. 
UNISIA, Vol. XXXI No. 70 Desember 2008

Mereka memperhatikan teks, mengalihkan kata-kata yang tertulis ke dalam pembicaraan imajinatif. Mereka memberikan ruang bagi teks untuk menentukan pointpointnya, dan membiarkannya mengkonter pra konsepsi mereka (atau horizonnya yang sekarang). Mereka menyadari bahwa teks memberikan sesuatu, bukan makna yang determinan tetapi kemungkinan interpretasi yang harus diisi yang relevan dengan dunia sekarang. Mereka berusaha meletakkan pertanyaan yang ditunjukkan oleh teks. Jawabannya adalah subjek dari teks, dan ini mirip dengan makna personal pengarang teks yang ditujukan kepada siswa-siswa (atau pembaca). Dengan memutar balik atau merefleksikan antara perubahan horizon dan arti literal yang terkandung dalam teks, para siswa mencari pesan yang terkandung dalam teks dan membuatnya bermakna secara personal (Kneller, Ibid).

Dalam bentuk analogi, Gadamer membandingkan proses pemahaman dengan game (permainan). Permainan ini bisa dimainkan oleh guru dan siswa-siswa secara bersama-sama atau oleh siswa sendiri dengan teks. Permainan mempunyai aturan-aturan; pemain tunduk kepada aturanaturan tersebut dan mengikuti langkahlangkah dalam permainan. Dalam permainan ini, pemain disuruh menebak makna yang ia ucapkan dalam teks. Teks ini atau apa yang diucapkan dari teks tersebut akan menariknya dalam sebuah permainan mencari makna yang tidak terhingga, dan biarkan pemain terus mengembangkan makna-maknanya. Dalam permainan ini, menurut Gadamer, kita tidak memainkan game sebanyak game itu memainkan kita. Dalam arti bahwa pencarian makna itu hanya sekedar secukupnya, hanya permainan, bukan larut dalam pencarian makna yang terus membebani pikiran kita, atau jangan sampai permainan itu terus mempermainkan kita. Permainan ini sama seperti kita bermain dengan teks. Struktur teks berhubungan dengan aturan-aturan dalam game. Masing-masing dari kita dapat memainkannya, berada dalam aturan-aturan tetapi mencapai hasil individual. Gambaran pemahaman seperti ini menuntut siswasiswa respek kepada teks dan menjadikannya bermakna bagi dirinya (Ibid).

Permainan, menurut Gadamer dapat merupakan semacam kerangka berpikir di dalam proses memahami yang menjadi pokok bahasan dalam hermeneutik. Dalam suatu permainan, misalnya main kartu, pemain tidak menyadari permainan itu sendiri sehingga permainan itu yang justru menguasai para pemainnya. Subjek permainan yang sesungguhnya bukan terletak pada pemainnya, tetapi permainan itu sendiri. Siapa pun yang ikut dalam permainan, ia menjadikan permainan itu betul-betul permainan. Untuk dapat bermain dengan baik, pertama-tama pemain harus mengetahui lebih dahulu aturan-aturan mainnya. Hal ini karena setiap game mempunyai aturan atau dinamika sendiri yang bersifat independen terhadap kesadaran para pemainnya. Kemudian, setelah pemain menguasai aturan-aturan dan dinamika permainan, maka ia akan tidak menyadari adanya peraturan tersebut, bahkan ia juga tidak menyadari permainan itu sendiri (Sumaryono,1999).

\section{Penutup}

Dengan mencermati uraian-uraian sebelumnya, dapat diambil intisari pembahasan sebagai berikut:

Pertama, hermeneutika mengambil model pemahaman dari wilayah human studies daripada natural sciences. Pemahaman tidak ubahnya seperti membaca teks atau mempelajari analog-analognya daripada 
Metode Hermeneutik dalam Pendidikan; Sembodo Ardi Widodo

mengobservasi objek. Sebuah teks selalu mempunyai makna, tetapi karena pengarangnya tidak hadir, meninggal, atau berasal dari kultur yang berbeda dengan kita, maka makna harus diinterpretasikan untuk kondisi waktu sekarang. Bagi hermeneutik, interpretasi adalah "hati" pemahaman. Pandangan ini akan cocok bagi guru karena perannya adalah untuk memahami manusia dan kreasi-kreasinya serta mengembangkan pemahaman ini kepada murid. Mengajar dalam perspektif hermeneutika adalah seni, bukan ilmu atau teknologi. Sebagai guru kita harus menanyakan apa makna materi pelajaran yang kita ampu bagi kita, dan apa maknanya bagi murid. Kita harus memperkenalkannya dan menolong murid untuk memahaminya. Dalam kacamata hermeneutik, core dari proses pembelajaran adalah membaca dan berdiskusi atas teks dan analog-analognya yang muncul secara spontan.

Kedua, menurut hermeneutik, kita memulai dengan pra-pemahaman terhadap teks dan analognya. Tanpa pra-pemahaman ini kita tidak memiliki ide apa yang sedang kita hadapi, lebih-lebih untuk dipahami. Sebagai seorang guru, kita bertanya kepada murid-murid untuk topik terlebih dahulu dalam cakrawala pengetahuan dan interesnya sekarang, dan kemudian menyuruhnya untuk memodifikasi sikapsikap mereka dalam merespon apa yang oleh topik dikatakan kepada mereka. Dengan cara ini mereka akan mengembangkan horizon mentalnya terhadap horizon topik. Inilah langkah kreatif dari pra pemahaman.

Ketiga, bagi hermeneutik, proses pembelajaran itu seperti dialog atau permainan di mana mereka yang terlibat dibawa oleh sesuatu yang lebih besar dari dirinya kepada pandangan yang tidak mereka antisipasi sebelumnya. Diskusi sejati tidak pernah direncanakan kemajuan dan hasilnya. Guru dan murid-murid berbicara secara spontan. Sebagaimana layaknya dalam permainan pemahaman, mereka bisa merubah pandangan atau respon-responnya terhadap teks tanpa batas.

\section{Daftar Pustaka}

Abdullah, H.M. Amin,2000. "KritisHermeneutis ala Muhammadiyah", dalam Suara Muhammadiyah, No. 12 Th. Ke-85 Juni.

, "Pembaharuan Pemikiran Islam Model Muhammadiyah", dalam Suara Muhammadiyah, No.16 / 81/ 1996.

Asrofie, M. Yusron, K.H. Ahmad Dahlan: Pemikiran dan Kepemimpinannya, Yogyakarta: Yogyakarta Offset, 1983.

Bleicher, Josef,2007. Hermeneutika Kontemporer, Terj. Imam Khoiri, Yogyakarta: Fajar Pustaka.

Djuwaeli, H.M. Irsjad,1997. Membawa mathla'ul Anwar ke Abad XXI, Jakarta: PB Mathla'ul Anwar.

Gadamer, Hermeneutics,1999. Religion, and Ethics, London: Yale University Press.

,1981. Reason in the Age of Science, Cambridge: Mass, M.I.T. Press.

Kneller, George F, 1984. Movements of Thought in Modern Education, New York: John Wiley \& Sons.

Nata, Abuddin,1997. Filsafat pendidikan Islam 1, Jakarta: Logos Wacana IImu,. 
UNISIA, Vol. XXXI No. 70 Desember 2008

Palmer, Richard E., 1969.Hermeneutics: Interpretation Theory in Schleiermacher, Dilthey, Heidegger, and Gadamer, Evanston: Northwestern University Press.

Ricoeur, Paul, 2005.Filsafat Wacana: Membelah Wacana dalam Anatomi Bahasa, Terj. Musnur Hery, Yogyakarta: IRCiSoD.
Sumaryono, E.,1999. Hermeneutik: Sebuah Metode Filsafat, Yogyakarta: Penerbit Kanisius.

Warnke, Georgia, 1987. Gadamer: Hermeneutics, Tradition and Reason, Cambridge: Polity Press. 